\title{
Irrigation Practices for Southern Highbush Blueberry in Florida ${ }^{1}$
}

\author{
Douglas A. Phillips and Jeffrey G. Williamson²
}

Southern highbush blueberries (SHB) have a shallow root system with no root hairs, which limits the capacity for water uptake and increases sensitivity to drought stress. SHB in Florida are typically planted either in pine bark beds prepared on top of the soil or in soil beds amended with pine bark, which provides organic matter and helps keep $\mathrm{pH}$ within the recommended 4.5-5.5 range. However, pine bark and Florida's sandy soils do not retain water very well, and SHB roots tend to stay within the pine bark layer (Figure 1). This requires modification to standard irrigation practices to keep the pine bark media sufficiently moist to meet plant water needs. This publication provides guidance on irrigation requirements and practices to Florida SHB growers.

\section{Water Movement and Plant Needs}

Water movement through the soil, plant, and atmosphere is governed by water potential (i.e., the potential energy of water), which consists of gravity potential (gravity acting to move water down through the soil profile), matric potential (the attraction of water to soil or substrate particles), and osmotic potential (water movement toward a solution with a lower concentration of water and more solutes, primarily influencing water uptake by the roots). Under typical conditions, water potential is highest in the soil or substrate, lowest in the atmosphere, and in between in the plant. Water moves from areas of higher water potential to lower water potential.

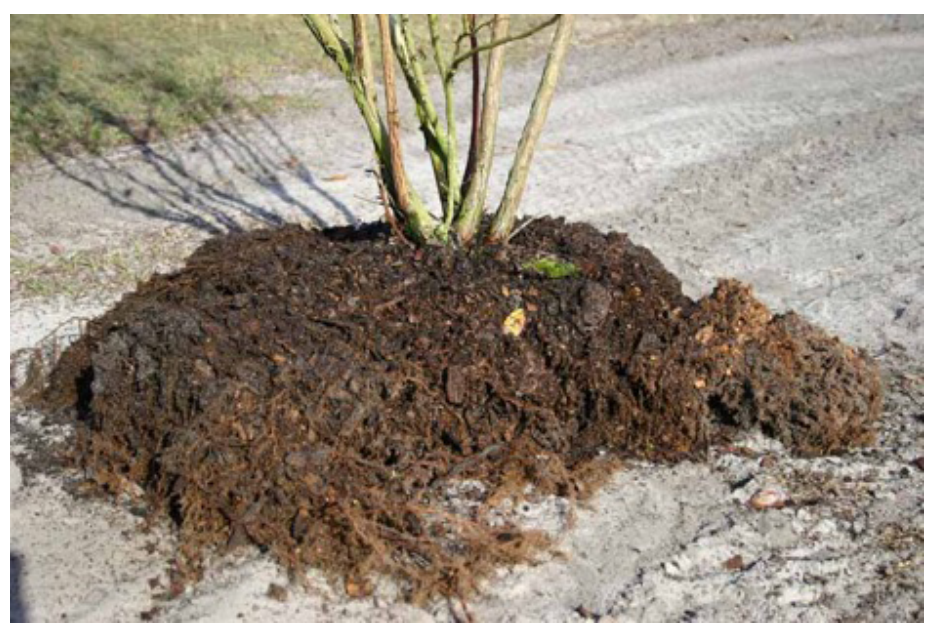

Figure 1. Excavated southern highbush blueberry plant grown in a pine bark bed. The shallow, fibrous root system was primarily limited to the depth of the pine bark, with very few roots penetrating the underlying soil.

When gravity has acted to drain all water not held in the soil by matric potential, the soil is at field capacity. As the plant transpires (losing water to the atmosphere through the leaf stomata), leaf water potential decreases and water is drawn up into the plant, decreasing the water potential in the soil. When the soil and plant water potentials are equal, the plant will no longer be able to take water up from the soil (referred to as the permanent wilting point), plant turgor pressure decreases, and the plant begins to wilt. The plant may recover at night when the leaf stomata close, but water must be added to the soil through irrigation or rainfall before reaching the permanent wilting point to

1. This publication is HS1432, one of a series of the Horticultural Sciences Department, UF/IFAS Extension. Original publication date December 2021. Visit the EDIS website at https://edis.ifas.ufl.edu for the currently supported version of this publication.

2. Douglas A. Phillips, blueberry Extension coordinator; and Jeffrey G. Williamson, professor, Horticultural Sciences Department; UF/IFAS Extension, Gainesville, FL 32611.

The Institute of Food and Agricultural Sciences (IFAS) is an Equal Opportunity Institution authorized to provide research, educational information and other services

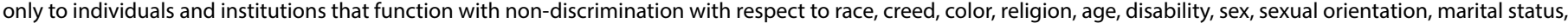

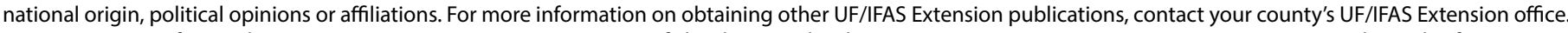
U.S. Department of Agriculture, UF/IFAS Extension Service, University of Florida, IFAS, Florida A \& M University Cooperative Extension Program, and Boards of County Commissioners Cooperating. Andra Johnson, dean for UF/IFAS Extension. 
avoid drought stress damage to the plant. This damage can include reduction in yield, fruit quality, and canopy growth; scorching of leaf margins; increased susceptibility to disease such as stem blight; and increased susceptibility to mite damage. It should be noted that continuing saturated soil conditions can lead to root disease such as Phytophthora and root damage due to low levels of oxygen (hypoxia).

Water use by blueberry plants is typically highest during fruit formation in the spring (when rainfall in Florida is low) and during summer and early fall canopy growth. Evapotranspiration (loss of water through evaporation from the soil and plant surfaces, and transpiration by the plant) will be higher during these periods. Water use can also vary depending on plant age, the size of the canopy, variety, planting density, environmental conditions, and production system.

In dormant (deciduous) systems, water use decreases in late fall and early winter, due to plant dormancy and defoliation. However, in evergreen systems the plants do not go dormant or defoliate, and plants will require a higher level of irrigation during this time than in a deciduous system.

\section{Irrigation Methods}

Overhead irrigation is used by a number of Florida growers to help meet irrigation needs. Most growers install overhead irrigation for freeze protection purposes and use it to supplement other irrigation sources. Overhead is relatively easy to install and maintain, and it provides uniform coverage of the field. Some growers also use it to apply fertilizer or pesticides. However, it is not very water efficient, depositing water in the row middles in addition to the beds. Overhead irrigation can also result in increased leaf wetness duration, leading to disease issues.

Drip irrigation is commonly used in Florida blueberry fields, both with and without weed mat. Two drip lines per row are typically used, with standard emitter spacing of 12 to 18 inches. Some types have openings formed as part of the manufacturing process, and some have emitters connected to the outside of the tubing. Irrigation water application efficiency is high compared to overhead, because the water is only applied to the plant bed, and drip irrigation can minimize infiltration below the root zone, reducing nutrient leaching. It can also be used for fertigation and the application of certain pesticides, can decrease the spread of fungal and algal disease, and can help reduce weed pressure. Cost-share programs for installing drip irrigation systems may be available through local water management districts.
One disadvantage is that water can move down in vertical channels through the pine bark bed, and a limited number of emitters per plant can result in uneven coverage of the laterally spreading root zone. If two drip lines are used, the emitters should be staggered to promote more even coverage. Uniformity of irrigation water application is important for proper, uniform plant growth. This can be evaluated by testing a sample of emitters for the volume of water applied, and by testing the pressure at points throughout each irrigation zone with a pressure gauge.

Emitter plugging can be an issue with drip irrigation, caused by physical (grit), biological (algae and bacteria), or chemical sources. Irrigation water from deep wells can include sand particles and other debris that may clog emitters. Algal and bacterial growth, especially in surface water irrigation, can build up within the system. These will sometimes combine with mineral particles to create blockages. High levels of calcium, magnesium, iron, or manganese can precipitate into scale, especially at a $\mathrm{pH}$ in excess of 7. This is common where there are high levels of calcium carbonate in deep well water. Proper filtration, chemical treatment for algae and bacteria (such as with chlorine), acid injection to help reduce the formation of precipitates, and regular flushing of the irrigation system are important to minimize emitter clogging.

Microjet irrigation is not heavily used in blueberry production in Florida, although a growing number of farms are installing it. Similar to drip irrigation, it can be focused on the plant bed and used for irrigation, fertigation, and pesticide application. One advantage over drip is that it can provide more uniform coverage of the root zone (possibly resulting in a larger root system, which could reduce plant stress). Microjet irrigation is also more water efficient and can minimize leaf wetness duration compared to overhead. However, microjet is not compatible with the use of weed mats and will generally use more water than drip irrigation.

It is important to periodically measure the flow rate of water through the irrigation system. Lower-than-normal flow rates may occur when there are obstructions in valves, pipes, or drip emitters, or they may indicate the need for pump adjustment or repair. If flow rates are higher than normal, this could mean that there are broken pipes or valves, or that too many irrigation zones are operating at the same time.There are various types of flow meters that can be used to measure flow rates. 


\section{Irrigation Management Suggestions}

A mature blueberry plant typically requires around 40 inches of water (irrigation and rainfall combined) annually. During periods of fruit development or high canopy growth, around 1 to 1.5 inches of water per week may be required. For example, mature 'Emerald' plants in north-central Florida used an average of about 2 gallons of water per day during the peak periods of water use in May and July through September. Irrigation water should be applied frequently and in relatively small amounts to avoid water loss below the root zone, especially in pine bark bed plantings where the roots are mainly limited to the bark media. For example, the upper 8 to 10 inches of pine bark amended sandy soil may only hold approximately an inch of water at field capacity. Overirrigation can lead to the leaching of water and nutrients below the root zone. During periods of high water demand, shorter-duration irrigation events applied multiple times per day will increase water use efficiency and reduce potential leaching of fertilizers and pesticides compared to longer, less frequent irrigation events. The frequency of irrigation events will also depend on weather conditions, cultivar, production system, and the use and condition of pine bark as a substrate or amendment. During fall and winter, plant water use decreases significantly in deciduous systems. For example, plant water use for mature 'Emerald' plants grown using the traditional dormant production system in north-central Florida decreased by about $40 \%$ in October (monthly average of $1.2 \mathrm{gal} /$ day) compared to September (monthly average of 2 gallons/day) and continued to decline from November (monthly average of $0.9 /$ gal/day) through January (monthly average of 0.4 gallons/day).

Irrigation water from deep wells in Florida often has a $\mathrm{pH}$ in excess of 7.0, which can rapidly increase soil and bark $\mathrm{pH}$. Many commercial growers inject sulfuric acid into the irrigation system to maintain the recommended substrate $\mathrm{pH}$ of 4.5-5.5. It is important to check soil and bark $\mathrm{pH}$ at least annually-more often when nutrient deficiency symptoms such as iron deficiency appear-and adjust as needed.

\section{Moisture Sensors}

Knowing when to apply irrigation is critical to meeting plant water needs in advance of drought stress. Soil moisture sensors can supply data on water content at different depths, providing growers with information needed for proper irrigation scheduling. This information can potentially reduce water use while maintaining or enhancing plant growth and fruit quality. The goal is to keep soil moisture within a targeted range by replacing water lost through evapotranspiration. Common groups of moisture sensor types include those that measure soil water content (volumetric), and those that measure soil water tension (the force of adhesion of water to soil particles). Sensors measuring soil water content can indicate both when and how much to irrigate. See EDIS publication BUL343, "Field Devices for Monitoring Soil Water Content" (https://edis. ifas.ufl.edu/ae266) for more details. Sensors measuring soil water tension may not work well in Florida conditions, especially in pine bark beds where they may lose suction. The difference between current soil water content as measured by volumetric sensors and the soil's field capacity (after gravity has drained all excess water not held by soil particles) is the soil water deficit, which is the amount of water that can be added through irrigation or rainfall that will not leach below the root zone.

Sensors should be placed in an accessible area away from field edges, in an area that is representative of the field in which it will be measuring moisture. Sensor depth should be within the root zone. Sensors placed at different depths will provide more information. Sensors placed close to the soil/bark surface will signal when to irrigate, and sensors at a lower depth (toward the bottom of the root zone) will indicate how far water has penetrated, indicating how much to irrigate. If only one sensor per site is used, it should be placed at a depth in the middle of the root zone. In fields with significant variability (e.g., slope, wetness, cultivar type, plant age, etc.), multiple sensor sites should be established.

\section{References}

Boman, B., and S. Shukla. 2019. "Water Measurement for Agricultural Irrigation and Drainage Systems." EDIS 2006 (17). https://doi.org/10.32473/edis-ch153-2006

Bryla, D. R. 2011. "Crop Evapotranspiration and Irrigation Scheduling in Blueberry." In Evapotranspiration: From Measurements to Agricultural and Environmental Applications, edited by Giacomo Gerosa. Rijeka, Croatia and Shanghai, China: InTech.

Clark, G., and D. Haman. 2017. "Microirrigation in Mulched Bed Production Systems: Irrigation Depths." EDIS 1994 (2). https://edis.ifas.ufl.edu/publication/AE049

Dukes, M., M. Shedd, and S. Davis. 2019. “Smart Irrigation Controllers: Operation of Evapotranspiration-Based 
Controllers.” EDIS 2019 (2). https://edis.ifas.ufl.edu/ publication/AE446

Haman, D. 2017. "Causes and Prevention of Emitter Plugging in Microirrigation Systems.” EDIS 1990 (2). https:// edis.ifas.ufl.edu/publication/AE032

Kisekka, I., K. Migliaccio, M. Dukes, J. Crane, B. Schaffer, H. Bayabil, and S. Guzman. 2019a. "EvapotranspirationBased Irrigation Scheduling for Agriculture.” EDIS 2019 (3). https://edis.ifas.ufl.edu/publication/AE457

Kisekka, I., K. Migliaccio, M. Dukes, J. Crane, B. Schaffer, H. Bayabil, and S. Guzman. 2019b. "EvapotranspirationBased Irrigation for Agriculture: Implementing Evapotranspiration-Based Irrigation Scheduling for Agriculture." EDIS 2019 (3). https://edis.ifas.ufl.edu/publication/AE458

Peters, R., K. Desta, and L. Nelson. 2013. "Practical Use of Soil Moisture Sensors and Their Data for Irrigation Scheduling." Washington State University Extension Fact Sheet FS083E. http://irrigation.wsu.edu/Content/Fact-Sheets/ FS083E.pdf

Retamales, J. B., and J. F. Hancock. 2012. "Blueberry Field Management and Harvesting.” In Blueberries, 143-192. Cambridge, MA: CABI. https://doi. org/10.1079/9781845939045.0143

Smajstrla, A. G., B. J. Boman, D. Z. Haman, D. J. Pitts, and F. S. Zazueta. 2018. "Field Evaluation of Microirrigation Water Application Uniformity." EDIS 1997 (1). https://edis. ifas.ufl.edu/publication/AE094

Williamson, J. G., and J. H. Crane. 2010. “Best Management Practices for Temperate and Tropical/Subtropical Fruit Crops in Florida: Current Practices and Future Challenges." HortTechnology 20 (1): 112-114. https://doi.org/10.21273/ HORTTECH.20.1.111

Williamson, J. G., L. Mejia, B. Ferguson, P. Miller, and D. Z. Haman. 2015. "Seasonal Water Use of Southern Highbush Blueberry Plants in a Subtropical Climate." HortTechnology 25 (2): 185-191. https://doi.org/10.21273/ HORTTECH.25.2.185

Zotarelli, L., M. Dukes, and K. Morgan. 2019. "Interpretation of Soil Moisture Content to Determine Soil Field Capacity and Avoid Over-irrigating Sandy Soils Using Soil Moisture Sensors.” EDIS 2010 (2). https://edis.ifas.ufl.edu/ publication/AE460
Zotarelli, L., C. Fraisse, and D. Dourte. 2018. "Agricultural Management Options for Climate Variability and Change: Microirrigation.” EDIS 2012 (7). https://edis.ifas.ufl.edu/ publication/HS1203 